\title{
Rancang Bangun Prototype Mesin Pemotong Rumput Kendali Jarak Jauh Menggunakan Aplikasi Android
}

\author{
M. Khairul Amri Rosa ${ }^{*}$, Reza Satria Rinaldi ${ }^{1}$, Ridho Illahi ${ }^{1}$ \\ ${ }^{1}$ Program Studi Teknik Elektro Universitas Bengkulu, *E-mail: amri@unib.ac.id
}

\begin{abstract}
This research develops a prototype of a remotely controlled lawn mower using Android smartphone with Bluetooth connection to avoid the risk of accidents. The lawn mower is controlled by an Android application developed with Mit App Inventor using HC-05 Bluetooth module connection. This prototype uses a DC motor as a driving motor to rotate the blade with an LM393 speed sensor using Arduino Uno microcontroller. The developed system is equipped with an option of grass height that can be adjusted. The test of HC-05 Bluetooth module resulted the maximum acceptable connection distance in the open space is $80 \mathrm{~m}$ and the maximum connection distance with a barrier is $10.45 \mathrm{~m}$. DC motor speed tests are carried out on the lawn mowers at no load and loaded conditions. The results showed a slight decrease in motor speed at the grass height of $6 \mathrm{~cm}$ and $4 \mathrm{~cm}$, but at $2 \mathrm{~cm}$ height the rotation dropped significantly.
\end{abstract}

Keywords: lawn mower, remote control, Arduino Uno, Bluetooth, Android

\begin{abstract}
AbSTRAK
Penelitian ini mengembangkan prototype mesin pemotong rumput kendali jarak jauh menggunakan smartphone Android dengan koneksi Bluetooth untuk menghindari resiko kecelakaan yang dapat terjadi. Alat pemotong rumput dikendalikan melalui aplikasi Android yang dikembangkan dengan Mit App Inventor dengan koneksi menggunakan modul Bluetooth HC-05. Protype ini menggunakan motor DC sebagai motor penggerak untuk memutar pisau dengan speed sensor LM393 menggunakan mikrokontroler Arduino Uno. Sistem yang dikembangkan dilengkapi ketinggian rumput yang dapat disesuaikan. Pengujian modul Bluetooth HC-05 menghasilkan jarak maksimal koneksi pada ruang terbuka $80 \mathrm{~m}$ dan jarak koneksi maksimal dari ruang tertutup sebesar 10,45 m. Pengujian putaran motor DC dilakukan pada keadaan mesin pemotong rumput tanpa beban dan berbeban. Hasil pengujian memperlihatkan terdapat sedikit penurunan kecepatan putaran motor pada ketinggian rumput $6 \mathrm{~cm}$ dan $4 \mathrm{~cm}$, sedangkan pada ketinggian $2 \mathrm{~cm}$ putaran turun dengan signifikan.
\end{abstract}

Kata kunci: pemotong rumput, remote control, Arduino Uno, Bluetooth, Android

\section{Pendahuluan}

Mesin pemotong rumput merupakan suatu alat perkakas rumah tangga yang digunakan untuk memotong rumput dengan cepat dan rapih, prinsipnya ditemukan oleh Edwin Beard Budding sekitar tahun 1830. Mesin pemotong rumput yang biasa digunakan di Indonesia ialah mesin pemotong rumput gendong yang menggunakan tenaga dari bahan bakar minyak (BBM). Resiko kecelakaan dapat saja terjadi sehingga membahayakan pengguna maupun orang-orang disekitarnya, seperti urat kaki putus akibat terkena pemotong rumput (Tribun Bali, 19 April 2017). Oleh karena itu sebuah sistem kendali jarak jauh dapat menghindari resiko seperti ini karena tidak mengharuskan pengguna berdekatan dengan mata pisau.

Beberapa penelitian mengenai mesin pemotong rumput otomatis telah dilakukan dengan berbagai metode. Mesin pemotong dengan program terpasang pada alat melalui keypad untuk mendefinisikan area yang akan dikerjakan [1]. Cara ini memiliki kerumitan dalam penentuan area dan juga tidak adanya umpan balik untuk hasil pemotongan. Peneltian lainnya adalah sistem kendali jarak jauh memanfaatkan gelombang radio frequency (RF) [2, 3], yang memerlukan peralatan khusus sebagai transmitter dan receiver-nya. Selain itu ada juga penelitian mengenai mesin pemotong rumput otomatis yang menggunakan limit switch sebagai sensor untuk mendeteksi adanya halangan [4].

Saat ini ponsel pintar dengan sistem operasi Android merupakan gawai yang umum dimiliki oleh setiap orang. Android merupakan sebuah sistem operasi pada ponsel berbasis Linux yang mencakup sistem operasi dan middleware. Fasilitas open source atau sistem operasi yang dapat dikembangkan dengan bebas bagi penggunanya sehingga yang menggunakannya dengan mengembangkan berbagai inovasi terhadap sistem operasinya maupun pada pembangunan aplikasi mobile. Ponsel ini dilengkapi dengan berbagai piranti canggih, termasuk kamera dan konektivitas nirkabel seperti wi-fi dan Bluetooth.

Pada penelitian ini dikembangkan sebuah sistem kendali jarak jauh mesin pemotong rumput 
menggunakan aplikasi Android pada smartphone dengan koneksi Bluetooth. Untuk dapat melihat area target pemotongan, mesin pemotong dilengkapi dengan kamera yang mengirimkan gambar ke layar ponsel.

\section{TinjauAn PUSTaKa}

Sistem kontrol jarak jauh adalah suatu alat untuk mengendalikan, memerintah dan mengatur keadaan dari suatu sistem dengan jarak jauh. Sistem kontrol jarak jauh ini berbasis otomatis dalam membantu kebutuhan dan kegiatan manusia, Teknologi sistem kontrol jarak jauh digunakan tanpa kabel agar cakupan jarak semakin luas, dan dapat mencapai tempat yang sulit dijangkau oleh manusia. Salah satunya menggunakan Android melalui Bluetooth sebagai remote control.

Pada masa saat ini sebagian besar vendor smartphone sudah memproduksi smartphone berbasis Android, seperti HTC, Motorola, Samsung, LG dan masih banyak vendor lainnya. Hal ini disebabkan karena Android adalah sistem operasi yang bersifat open source sehingga bebas didistribusikan dan dipakai oleh vendor manapun.

Bagian-bagian dasar dari mesin pemotong rumput dengan kendali jarak jauh menggunakan aplikasi Android dengan koneksi Bluetooth mempunyai bagianbagian utama sebagai berikut:

- Sistem penggerak roda dan pemutar pisau

- Modul Bluetooth

- Pengendali Arduino UNO

- Sistem daya

- Smartphone Android

\section{A. Motor DC}

Motor DC merupakan satu jenis motor elektrik yang mengkonversi energy listrik arus searah menjadi energy mekanik. Umumnya motor DC bekerja berdasarkan gaya yang dihasilkan oleh medan magnetik. Hampir semua jenis motor DC mempunyai mekanisme internal, baik secara elektromekanik atau elektronik, untuk mengubah arah arus yang mengalir pada bagian motor secara periodik.

Pada ukuran yang kecil, motor DC umumnya dipilih sebagai penggerak pada berbagai peralatan portable yang menggunakan sumber daya DC yang berasal dari baterai karena kemudahan dalam pengaturan kecepatannya. Kecepatan motor DC dapat dikontrol pada range yang luas menggunakan tegangan suplay variabel atau melalui perubahan kuat arus pada kumparan medannya [5].

Motor DC brushless menggunakan magnet permanen untuk menggantikan kumaran pada statornya dengan rangkaian elektronika digunakan untuk

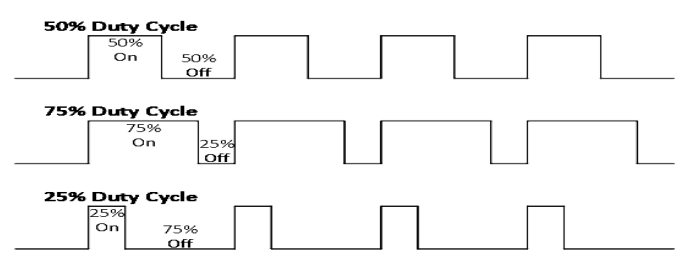

Gambar 1. Bentuk gelombang output PWM

mengubah arus AC menjadi DC. Kelebihan motor jenis ini adalah mempunyai efisiensi yang tinggi dan hampir tidak memerlukan perawatan. Magnet permanen menghasilkan medan magnetik yang konstan, sehingga kontrol kecepatan dilakukan hanya dengan mengatur tegangan suplay. Kecepatan motor DC ditentukan dengan:

$$
n=\frac{V_{T}-I_{A} R_{A}}{k . \phi}
$$

dimana,

$$
\begin{aligned}
n & =\text { putaran motor } \\
V_{T} & =\text { tegangan suplay } \\
I_{A} & =\text { arus jangkar } \\
R_{A} & =\text { tahanan jangkar } \\
k & =\text { konstanta mesin } \\
\phi & =\text { fluks magnetik }
\end{aligned}
$$

\section{Pulse Width Modulation}

Tegangan suplay variabel yang diberikan kepada motor DC dapat dihasilkan menggunakan metode pulse width modulation (PWM). PWM merupakan suatu metode untuk menurunkan tegangan dan arus rata-rata yang diberikan kepada beban dengan mengatur penyalaan (on) dan pemadaman (off) sakelar elektronik yang menghubungan sumber ke beban secara periodik dengan sangat cepat [6]. Perintah untuk penyalaan dan pemadaman tersebut dilakukan melalui pengendali, yaitu IC atau mikrokontroler, yang memberikan sinyal kepada sakelar. Perbandingan waktu on $\left(T_{o n}\right)$ dan periode $(T=$ $T_{\text {on }}+T_{\text {off }}$ ) disebut dengan duty cycle.

$$
D=\frac{T_{\text {on }}}{T}=\frac{T_{\text {on }}}{T_{\text {on }}+T_{\text {off }}}
$$

Bentuk gelombang output pada beberapa variasi duty cycle diperlihatkan Gambar 1.

\section{H-Bridge}

Pengaturan putaran motor dapat dilakukan dengan konfigurasi H-Bridge, seperti Gambar 2. Konfigurasi ini digunakan untuk menjalankan motor DC, mengubah kecepatan, membalik putaran, atau menghentikan putaran motor dengan kontrol logika. 


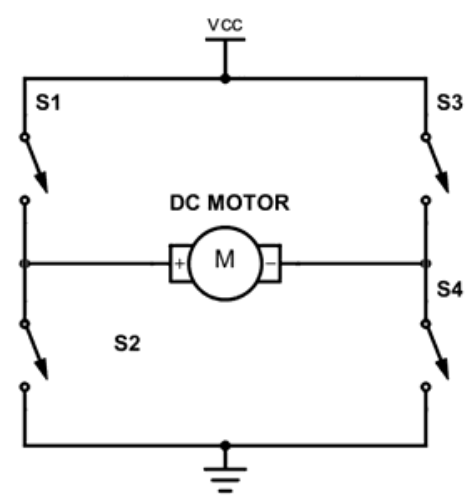

Gambar 2. Rangkaian dasar H-Bridge (sumber: build-electronic-circuits.com)

Rangkaian $\mathrm{H}$-Bridge dapat dibuat dari rangkaian dengan IC yang sudah dirancang khusus seperti L293D, SN754410NE, L298, LMD18200.

\section{B. Modul Bluetooth}

Modul HC-05 adalah modul Bluetooth yang dapat berfungsi sebagai master atau sebagai slave. Modul HC05 memiliki dua mode kerja yaitu mode AT Command dan mode Data. Modul HC-05 menggunakan mode Data secara default. Berikut ini adalah keterangan untuk kedua mode tersebut:

\section{AT Command}

Pada mode ini, modul HC-05 akan menerima instruksi berupa perintah AT Command. Mode ini dapat digunakan untuk mengatur konfigurasi modul HC-05. Perintah AT Command yang dikirimkan ke modul HC-05 menggunakan huruf kapital dan diakhiri dengan karakter CRLF (|r|n atau 0x0d 0x0a dalam heksadesimal).

2. Data

Pada mode ini, modul HC-05 dapat terhubung dengan perangkat Bluetooth lain dan mengirimkan serta menerima data melalui pin TX dan RX. Konfigurasi koneksi serial pada mode ini menggunakan baudrate: 9600 bps, data: 8 bit, stop bits: 1 bit, parity: None, handshake: None.

\section{Arduino Uno}

Arduino Uno merupakan salah satu jenis modul Arduino yang menggunakan mikrokontroler Atmega328. Penggunaan Arduino sangat beragam misalnya untuk pengembangan obyek interaktif, pusat kontrol sistem telemetri, pusat kontrol robot edukasi serta masukan dari berbagai switch atau sensor. Dalam menjalankan perintah, Arduino Uno menggunakan bahasa pemrograman $\mathrm{C} / \mathrm{C}++$ dan disempurnakan dengan adanya library dasar yang lengkap [7].

Platform Arduino sering digunakan pada berbagai

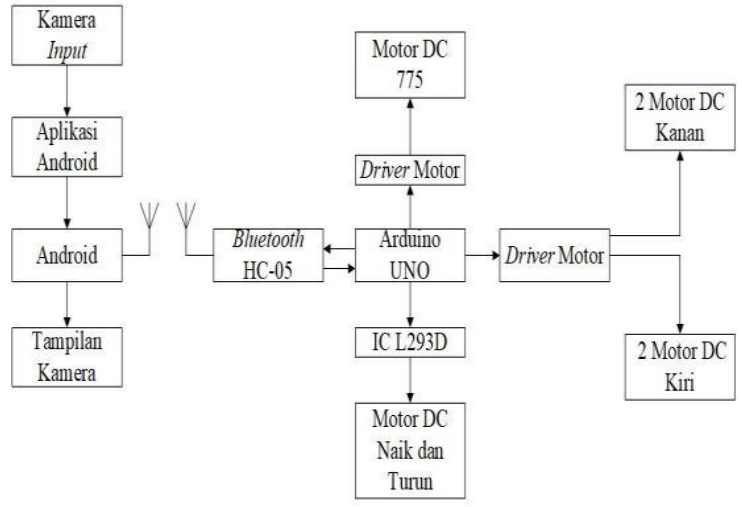

Gambar 3. Diagram blok sistem pemotong rumput kendali jarak jauh

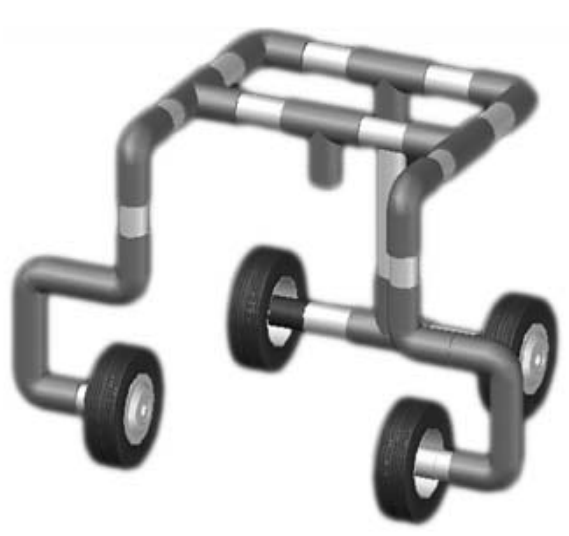

Gambar 4. Rangka mesin pemotong rumput

aplikasi kelistrikan dan elektronika. Arduino juga telah dipergunakan dengan baik untuk meningkatkan fungsionalitas motor DC brushless untuk menaikkan serta menurunkan kecepatan motor, termasuk dengan kendali wireless dengan sinyal yang diterima dari pemancar RC [5].

\section{Metode Penelitian}

Rancangan penilitian yang akan dilakukan terdiri dari beberapa tahap perancangan yaitu tahapan pembuatan perangkat keras (hardware) dan tahapan perancangan lunak (software). Pada bagian ini akan menjelaskan perancangan secara umum dari sistem kerja alat pemotong rumput yang diinginkan. Gambar 3 memperlihatkan diagram blok sistem.

\section{A. Desain hardware}

Perangkat keras (hardware) yang dipergunakan pada pembuatan prototype ini terdiri dari rangka mesin, kamera, mikrokontroler Arduino Uno, ponsel Android, modul Bluetooth HC-05, driver motor L298N, IC L293D, motor DC 775 dan motor DC GA25Y370.

Rangka prototype mesin pemotong rumput dibuat 
TABEL 1

SPESIFIKASI ARDUINO UNO

\begin{tabular}{lc}
\hline \multicolumn{1}{c}{ Spesifikasi } & Nilai \\
\hline Mikrokontroler & ATmega 328 \\
Tegangan Operasi & $5 \mathrm{~V}$ \\
Tegangan Input & $7 \mathrm{~V}-12 \mathrm{~V}$ \\
Batas Tegangan Input & $6 \mathrm{~V}-20 \mathrm{~V}$ \\
Digital I/O Pins & $14(6 \mathrm{PWM})$ \\
Analog Input & 6 \\
Arus DC tiap Pins I/O & $40 \mathrm{~mA}$ \\
Flash Memory & $32 \mathrm{~KB}$ \\
SRAM & $2 \mathrm{~KB}$ \\
EEPROM & $1 \mathrm{~KB}$ \\
Clock Speed & $16 \mathrm{MHz}$ \\
\hline
\end{tabular}

TABEL 2

SPesifiKasi Modul Bluetooth HC-05

\begin{tabular}{lc}
\hline \multicolumn{1}{c}{ Spesifikasi } & Nilai \\
\hline Protokol Bluetooth & Bluetooth v2.0 + EDR \\
Frekuensi & $2.4 \mathrm{GHz}$ ISMband \\
Modulasi & GFSK \\
Emisi Daya & $4 \mathrm{dBm}$, Class 2 \\
Sensitivitas & $0-84 \mathrm{dBm}$ at $0.1 \%$ BER \\
Kecepatan Asinkronus & $2.1 \mathrm{Mbps}$ (Max) $/ 160 \mathrm{kbps}$ \\
Kecepatan Sinkronus & $1 \mathrm{Mbps} / 1 \mathrm{Mbps}$ \\
Keamanan & Authentication andencryption \\
Profil & Bluetooth serialport \\
Power Supply & $+3.3 \mathrm{VDC} 50 \mathrm{Ma}$ \\
Temperatur & $-20 \sim+75$ Centigrade \\
Dimensi & $3.57 \mathrm{~cm} \times 1.52 \mathrm{~cm}$ \\
\hline
\end{tabular}

menggunakan pipa PVC 3/4" dengan 4 roda yang masingmasing digerakkan oleh 1 motor DC seperti diperlihatkan Gambar 4.

Seperti terlihat pada diagram blok sistem Gambar 3, terdapat 2 input pada sistem yaitu aplikasi Android dan kamera. Pusat pemrosesan pada desain sistem di atas dilakukan oleh Arduino Uno. Output sistem berupa 1 motor DC untuk naik dan turun mata pisau, 4 motor DC sebagai penggerak dan 1 motor DC sebagai penggerak pisau pemotong rumput, serta hasil tangkapan kamera pada layar ponsel Android.

\section{Spesifikasi piranti}

Arduino Uno

Arduino Uno adalah board mikrokontroler berbasis ATmega328 (data sheet). Memiliki 14 pin input dan output digital dimana 6 pin input tersebut dapat digunakan sebagai output PWM dan 6 pin input analog, $16 \mathrm{MHz}$ osilator kristal, koneksi USB, jack power, ICSP header, dan tombol reset. Spesifikasi Arduino Uno diberikan pada Tabel 1.

Modul Bluetooth HC-05
TABEL 3

SPESIFIKASI MOTOR DC

\begin{tabular}{lcc}
\hline \multirow{2}{*}{ Spesifikasi } & \multicolumn{2}{c}{ Nilai } \\
\cline { 2 - 3 } & Penggerak roda & Penggerak pisau \\
\hline Tipe & GA25Y370 & 775 \\
Tegangan & $6 \mathrm{v}-12 \mathrm{v}$ & $12 \mathrm{~V}-36 \mathrm{~V}$ \\
Panjang keseluruhan & $59 \mathrm{~mm}$ & $98 \mathrm{~mm}$ \\
Diameter & $25 \mathrm{~mm}$ & \\
Diameter sumbu & $4 \mathrm{~mm}$ & $5 \mathrm{~mm}$ \\
Panjang sumbu & $11 \mathrm{~mm}$ & $17 \mathrm{~mm}$ \\
Kecepatan tanpa beban & $120 \mathrm{rpm}$ & $3500-9000 \mathrm{rpm}$ \\
Arus & $0,13 \mathrm{~A}$ & $0,14 \mathrm{~A}-0,20 \mathrm{~A}$ \\
Torka & $6,4 \mathrm{Kg}-\mathrm{cm}$ & $2 \mathrm{~kg}-\mathrm{cm}$ \\
\hline
\end{tabular}

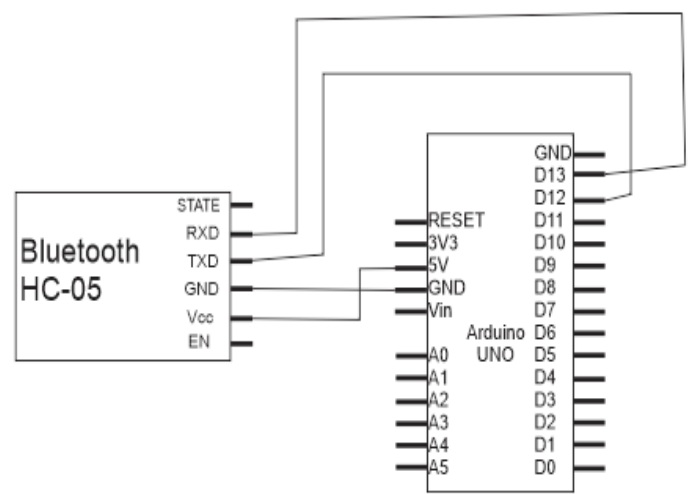

Gambar 5. Jalur pin dari Bluetooth HC-05 ke Arduino Uno.

Modul Bluetooth HC-05 berfungsi sebagai penghubung Android dengan Arduino Uno. Tabel 2 menampilkan spesifikasi modul Bluetooth HC-05.

\section{Motor DC}

Pada prototype ini digunakan 2 jenis motor DC, yaitu motor DC tipe GA25Y370 berjumlah 5 unit, 4 sebagai penggerak dan 1 sebagai penggerak ketinggian mata pisau, serta motor DC model 775 sebagai penggerak pisau pemotong rumput. Spesifikasi kedua motor tersebut diberikan pada Tabel 3.

\section{Modul driver motor DC}

Modul driver motor DC yang digunakan adalah Modul Driver Motor L298N untuk motor penggerak roda dan penggerak mata pisau. Sedangkan untuk menaik-turunkan mata pisau digunakan IC L293D.

\section{Rangkaian Modul Bluetooth}

Pin VCC pada Bluetooth HC-05 dihubungkan ke pin 5v Arduino Uno. Pin GND pada Bluetooth HC-05 dihubungkan ke pin GND Arduino Uno. Pin TXD pada Bluetooth HC-05 dihubungkan ke pin D12 Arduino Uno. Pin RXD Bluetooth HC-05 dihubungkan ke pin D13 Arduino Uno. Rangkaian modul rangkaian Bluetooth HC05 dengan Arduino Uno diperlihatkan pada Gambar 5. 


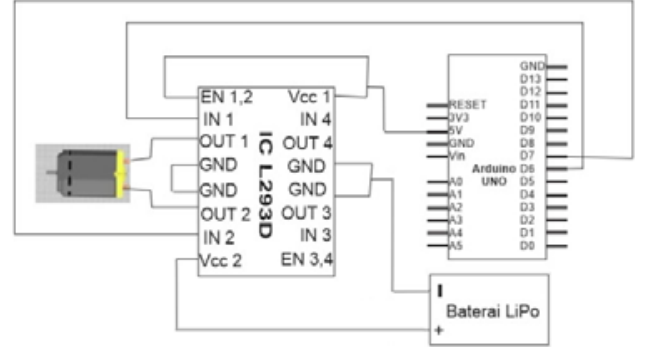

Gambar 6. Rangkaian Pengatur Ketinggian Pisau

\section{Rangkaian Pengatur Ketinggian Pisau}

Rangkaian ini merupakan pengendali naik dan turun pisau pemotong rumput untuk mengatur tinggi rumput yang dipotong sesuai yang diinginkan. Komponen yang digunakan adalah IC L293D, motor DC dan limit switch yang dihubungkan dengan Arduino. IC L293D dan Arduino digunakan untuk mengontrol atau mengendalikan kecepatan dan arah putaran motor DC, sedangkan limit switch digunakan untuk mematikan motor.

Pada Gambar 6 dapat dilihat jalur pin untuk rangkaian pengatur ketinggian pisau. Tegangan input pada baterai LiPo dihubungkan ke pin Vcc 2 pada IC L293D. Pin Out 1 dan Out 2 IC L293D dihubungkan ke motor DC. Pin In 1 IC L293D dihubungkan ke pin D6 pada Arduino Uno. Pin In 2 IC L293D dihubungkan ke pin D7 pada Arduino Uno. Ground pada IC L293D saling dihubungkan. Pin En 1,2 dan Vec 1 IC L293D dihubungkan ke pin $5 \mathrm{~V}$ pada Arduino Uno.

\section{Rangkaian Kontrol}

Rangkaian kontrol digunakan untuk proses kendali pada sistem pemotong rumput jarak jauh. Arduino Uno dengan driver motor digunakan untuk mengontrol atau mengendalikan kecepatan dan arah pergerakan motor terutama untuk motor DC. Speed sensor LM393 berfungsi untuk membaca rpm putaran yang dihasilkan pada motor DC. Sebagai sumber daya digunakan dua buah baterai litium polimer, masing-masing dengan tegangan12 dan $16 \mathrm{~V}$. Rangkaian kontrol sistem pemotong rumput jarak jauh yang dibuat diperlihatkan oleh Gambar 7.

Pin ln 4 pada driver motor 1 dihubungkan ke pin D3 pada Arduino. Pin $\ln 3$ pada driver motor 1 dihubungkan ke pin D5 pada Arduino. Pin $\ln 2$ pada driver motor 1 dihubungkan ke pin D9 pada Arduino. Pin $\ln 1$ pada driver motor 1 dihubungkan ke pin D10 pada Arduino. pin GND pada driver motor 1, driver motor 2, LM393 saling dihubungkan ke pin GND pada Arduino serta kutub negatif pada baterai LiPo juga dihubungkan pada pin GND di Arduino. Pin Vin driver

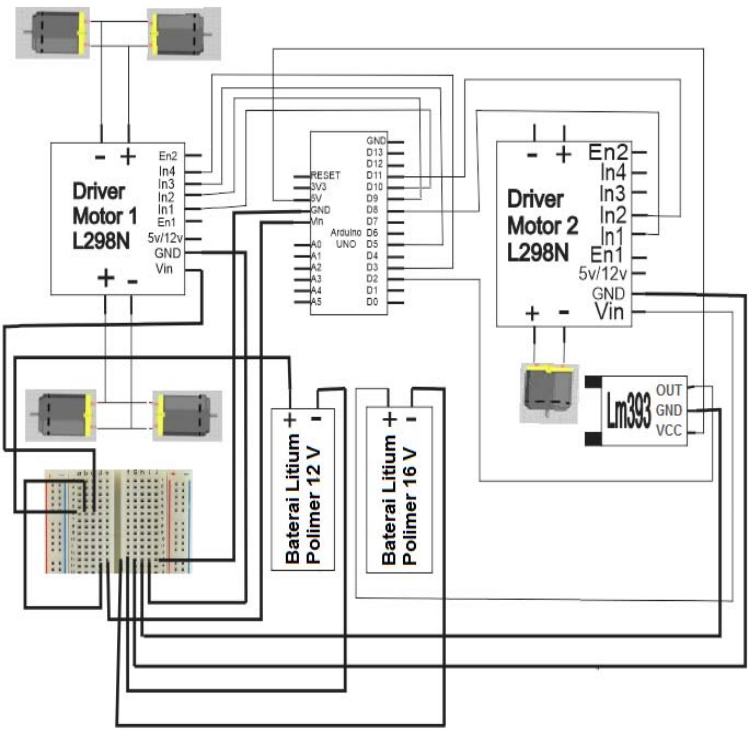

Gambar 7. Rangkaian kontrol Mesin Pemotong Rumput muka sistem pengendali.

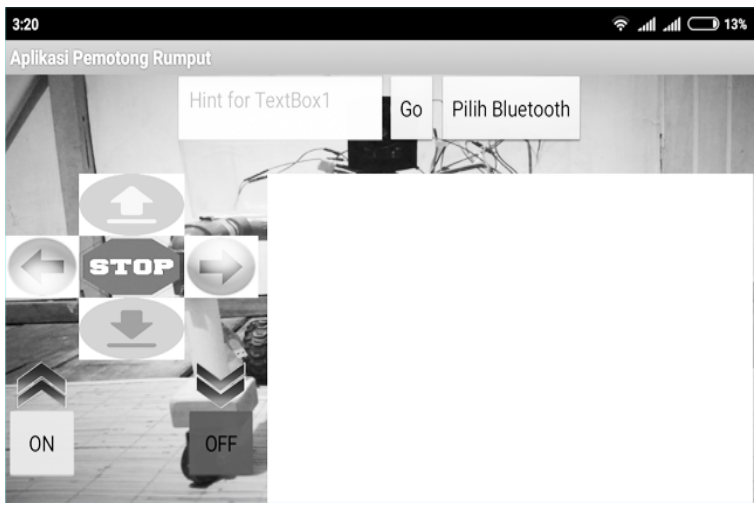

Gambar 8. Desain antar muka aplikasi Android

motor 1 dan kutub positif baterai LiPo $12 \mathrm{v}$ saling dihubungkan ke pin Vin pada Arduino. Pin $\ln 1$ driver motor 2 dihubungkan ke pin D8 pada Arduino. Pin $\ln 2$ driver motor 2 dihubungkan ke pin D11 pada Arduino. Pin Vin driver motor 2 dihubungkan ke kutub positif baterai 16 v. Pin out LM393 dihubungkan pada pin D2 Arduino. Pin Vcc LM393 dihubungkan pada pin 5v Arduino.

\section{B. Desain Software}

Desain perangkat lunak atau software terdiri dari 2 bagian, yaitu pembuatan aplikasi Android dan pemrograman mikrokontroler.

Aplikasi Android prototype pemotong rumput dengan kendali jarak jauh dikembangkan menggunakan perangkat lunak MIT App Inventor. Pada program ini dikembangkan desain halaman depan aplikasi dan antar

Desain aplikasi sistem pengendali Gambar 8 memperlihatkan susunan objek-objek kontrol untuk mengendalikan mesin pemotong rumput. Aplikasi 


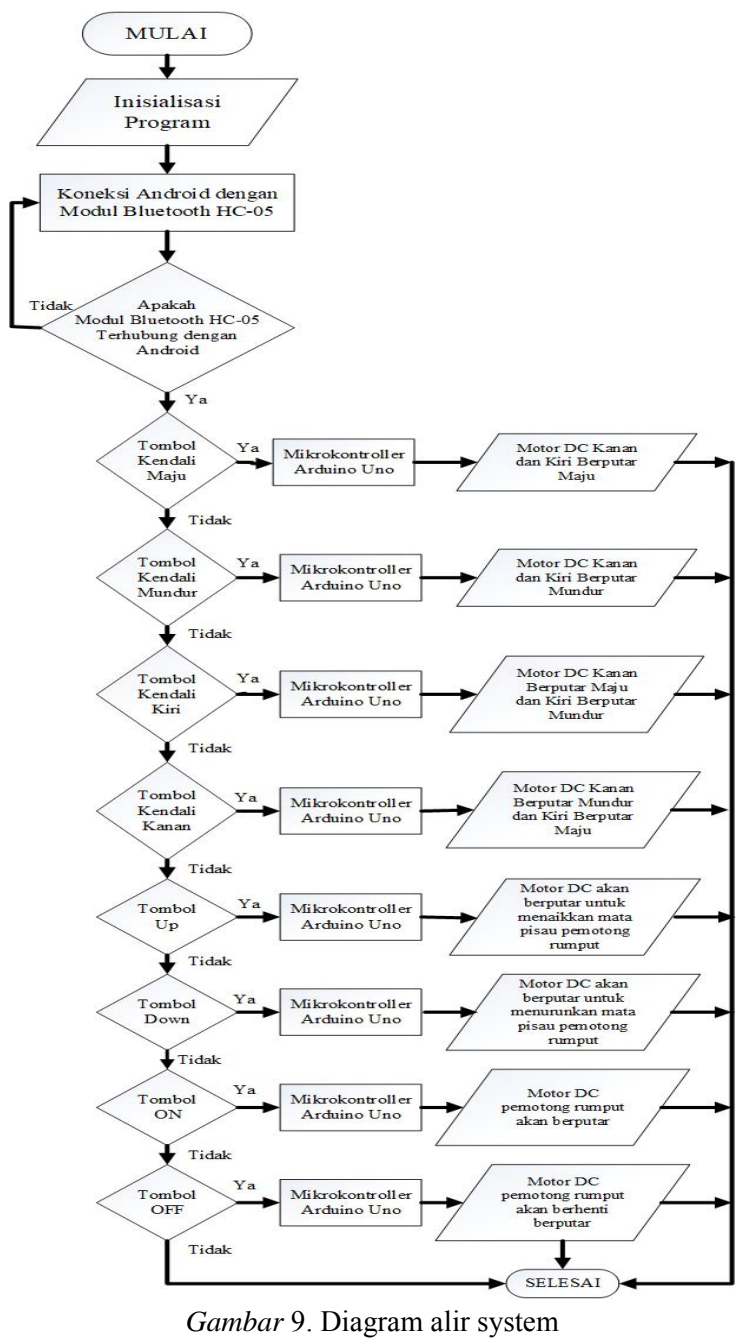

Android ini berfungsi sebagai remote control dan kotak berwarna putih akan memperlihatkan tangkapan kamera untuk melihat kondisi sekitar.

Sedangkan pemrograman mikrokontroler dilakukan menggunakan integrated development environment (IDE) Arduino berdasarkan diagram alir pada Gambar 9.

\section{HaSil dan PEMbahasan}

Setelah menyelesaikan tahap desain dan pembuatan alat, selanjutnya dilakukan pengujian terhadap prototype yang telah dibuat untuk memeriksa apakah tiap bagian sistem telah bekerja dengan baik. Hal ini dilakukan agar tidak terjadi kerusakan alat ketika pengujian keseluruhan dilaksanakan.

\section{A. Pengujian Respon Waktu Koneksi Bluetooth}

Pengujian ini dilakukan dengan menghubungkan alat pemotong rumput menggunakan modul Bluetooth HC-05 kepada Bluetooth pada ponsel Android. Pengujian ini dilakukan dengan 2 perlakuan dan 2 tahapan. Pada perlakuan pertama dilakukan pengujian jarak koneksi Bluetooth terhadap respon waktu pada

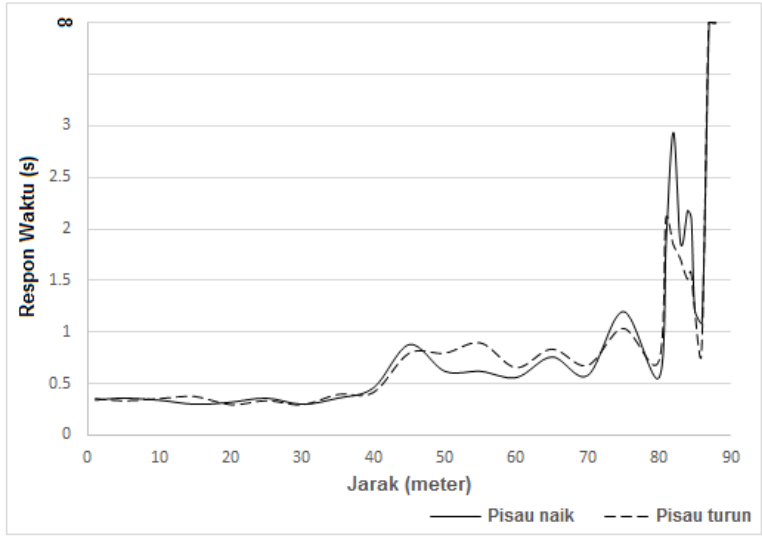

(a)

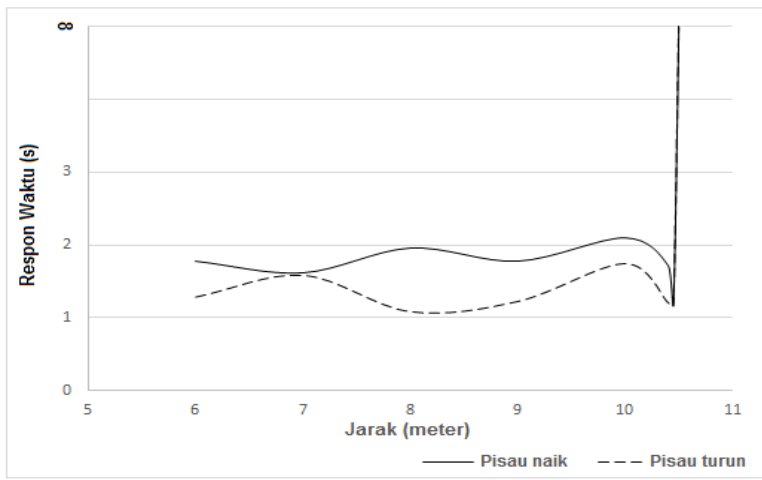

(b)

Gambar 10. Grafik Pengujian Jarak Koneksi Bluetooth terhadap Respon Waktu

(a) kondisi line of sight, (b) dari ruang tertutup

kondisi line of sight (LOS) untuk menurunkan dan menaikkan pisau. Pada perlakuan selanjutnya dilakukan pengujian jarak koneksi Bluetooth terhadap respon waktu untuk menaikkan dan menurunkan mata pisau dari ruangan tertutup.

Grafik pengujian jarak koneksi Bluetooth terhadap respon waktu pada kedua perlakuan tersebut diperlihatkan pada Gambar 10(a) dan 10(b).

Gambar 10(a) memperlihatkan pada kondisi line of sight menunjukkan bahwa koneksi Bluetooth pada jarak kurang dari $80 \mathrm{~m}$ cukup stabil dengan rata-rata respon waktu $0,56 \mathrm{~s}$. Koneksi masih dapat berlangsung hingga jarak 86 meter tetapi tidak dapat menghasilkan koneksi yang stabil.

Sedangkan pengujian koneksi Bluetooth dari ruang tertutup pada Gambar 10(b) memperlihatkan koneksi berlangsung hingga jarak 10,45 $\mathrm{m}$ dan terputus pada jarak di atasnya. Koneksi berlangsung cukup stabil meskipun respon waktunya lebih lama.

\section{B. Pengujian Tanpa Beban}

Pengujian ini dilakukan menggunakan motor DC 


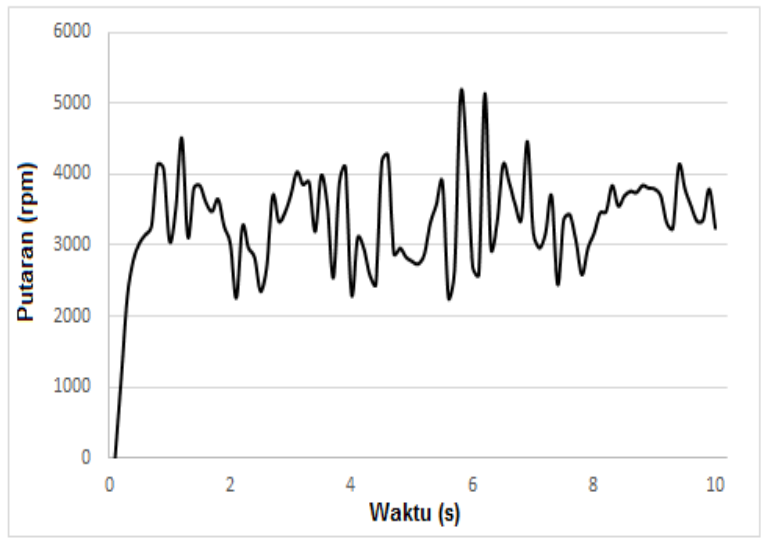

Gambar 11. Grafik Pengujian Putaran Tanpa Beban

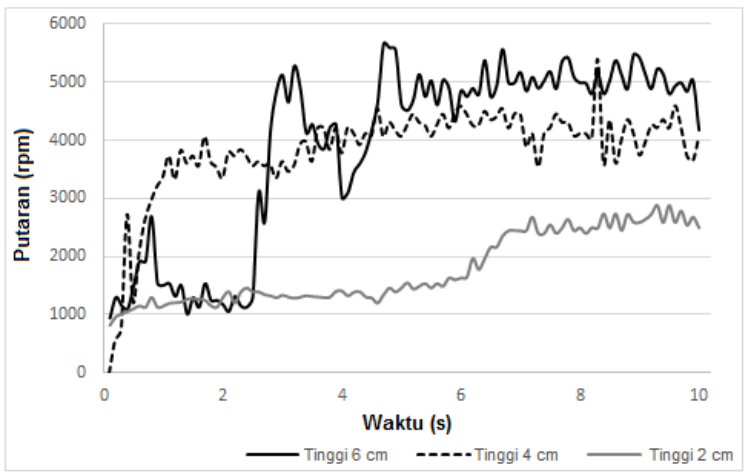

Gambar 12. Grafik pengujian dengan variasi beban

775 yang digunakan untuk motor pemotong rumput. Pada pengujian ini untuk mengetahui putaran motor DC dengan perbandingan waktu dan speed sensor LM393, pada pengujian ini dilakukan dengan tahapan tanpa beban dan berbeban.

Pengujian tanpa beban dilakukan dengan perbandingan antara waktu dan speed sensor LM393. Data pengujian tanpa beban dapat dilihat pada lampiran. Hasil pengujian tanpa beban dapat dilihat pada Gambar 11.

Berdasarkan Gambar 11 menunjukkan pengujian putaran tanpa beban dengan waktu 10 detik dengan interval pengukuran pada serial monitor 0,1 detik. Pada pengujian ini terlihat bahwa grafik pengujian putaran tanpa beban yang dihasilkan tidak stabil. Ketidakstabilan ini akibat pembacaan sensor LM393 terhadap kecepatan putaran motor DC kurang akurat. Faktor yang menyebabkan tidak akuratnya speed sensor LM393 dalam pembacaan kecepatan dikarenakan sensitivitas inframerah pada sensor terganggu akibat adanya pantulan cahaya dari lingkungan sekitar.

\section{Pengujian Dengan Variasi Beban}

Pada pengujian selanjutnya dilakukan pengujian putaran dengan pembebanan selama 10 detik dengan jumlah rpm yang terbaca pada serial monitor sebanyak 100 data. Pengujian ini dilakukan dengan 3 tingkatan setting ketinggian rumput. Ketinggian pemotongan rumput diatur berturut-turut adalah 6,4 , dan $2 \mathrm{~cm}$.

Grafik hasil pengujian putaran dengan variasi beban dapat dilihat pada Gambar 12.

Dari grafik hasil pengujian dengan variasi beban terlihat bahwa pada beban 1, prototype mampu mengatasi beban dengan kecepatan pada kisaran 5000 rpm. Ketika ketinggian rumput diturunkan, prototype masih mampu mengatasi beban meskipun terjadi penurunan kecepatan. Sedangkan pada ketinggian $2 \mathrm{~cm}$, kecepatan putaran motor jauh menurun, disebabkan beban yang bertambah, dimana kerapatan rumput semakin tinggi dan semakin dekat dengan akar rumput.

Grafik hasil pengujian juga memperlihatkan bahwa pembacaan sensor kecepatan LM393 masih belum stabil.

\section{KESIMPULAN}

1. Sistem dapat dikendalikan dengan baik hingga jarak $80 \mathrm{~m}$ pada keadaan line of sight pada ruang terbuka. Sedangkan pengendalian dari ruang tertutup, jarak maksimal yang dapat dijangkau oleh prototype sebesar $10,45 \mathrm{~m}$.

2. Dari hasil pengujian didapatkan bahwa pemotongan rumput dapat dilakukan dari dalam ruangan tertutup dengan jarak maksimal 10,45 $\mathrm{m}$ dengan menggunakan bantuan tangkapan kamera pada layar ponsel Android.

3. Kecepatan motor sangat dipengaruhi oleh beban yang diterapkan kepada sistem. Ketika kerapatan rumput bertambah, kecepatan motor berkurang dengan signifikan, sehingga dibutuhkan sistem kendali yang baik untuk menjaga kecepatan motor konstan.

4. Pembacaan sensor kecepatan LM393 tidak stabil akibat pengaruh eksternal. Oleh sebab itu diperlukan perbaikan terhadap desain untuk meningaktkan keakuratan pembacaan.

\section{REFERENSI}

[1] A. Yusup, M. Arkanuddin, T. Sutikno, "Perancangan Model Alat Pemotong Rumput Otomatis Berbasis Mikrokontroler AT89C51", Jurnal Ilmiah Teknik Elektro Komputer dan Informatika, Universitas Ahmad Dahlan, Yogyakarta, e-ISSN 2338-3062 p-ISSN 2338-3070, Vol. 1 No.1 Juli 2015, hal. 21-32.

[2] N. Rudita, "Perancangan dan Pembuatan Purwarupa Alat Pemotong Rumput Tenaga Listrik Dengan Kendali Jarak Jauh”, Sekolah Vokasi Universitas Gadjah Mada, Yogyakarta, 2016.

[3] R. Febrianto, "Rancang Bangun Prototype Kapal Pembersih Sampah dengan Sistem Kendali Radio RF", Universitas Bengkulu, Bengkulu, 2015.

[4] J. Akay, J. Wuwung, B. Sugiarso, A. Lumenta, "Rancang Bangun Alat Pemotong Rumput Otomatis", Jurnal Teknik Elektro dan Komputer Universitas Sam Ratulangi, e-ISSN: 2685-368X p-ISSN: 2301-8402, Vol. 2 No. 4, 2013. 
Jurnal Amplifier Mei 2019 Vol 9 No 1 P-ISSN 2089-2020 dan E-ISSN 2622-2000

[5] V. Mach, S. Kovář, J. Valouch, M. Adámek, "Brushless DC Motor Control on Arduino Platform", Przegląd Elektrotechniczny, Polandia, ISSN 0033-2097, November 2018.

[6] B. Prabowo, "Pemodelan Sistem Kontrol Motor DC dengan Temperatur Udara sebagai Pemicu”, Jurnal INKOM Lembaga Ilmu Pengetahuan Indonesia, e-ISSN: 2302-6146 p-ISSN: 1979-8059, Vol. 2 No. 1, 2008.
[7] J. Boxall, "L298N Dual Motor Controller Module 2A and Arduino”, Tronix Lab, Australia, 2014. 